\title{
Analisis Penentuan Rute Terbaik Menggunakan Shortest Route Problem dengan Metode UNSY untuk Meminimalisir Biaya Transportasi
}

\author{
Aulia Hamada $^{* 1)}$, Karina Muryastuti ${ }^{2)}$, Yudi Hartono ${ }^{3)}$, dan Yuniaristanto ${ }^{4)}$ \\ ${ }^{123)}$ Mahasiswa Program Studi Teknik Industri, Fakultas Teknik, Universitas Sebelas Maret \\ ${ }^{4)}$ Dosen Program Studi Teknik Industri, Fakultas Teknik, Universitas Sebelas Maret \\ Jl. Ir. Sutami No 36A, Surakarta 57126
}

\begin{abstract}
Printpro is printing industry. Printpro is located at Kauman, Surakarta. Printpro produces some products such as invitation cards, calenders, and hardcovers. It makes every costomers in Printpro are new costomers. The new customers' address which is never known before makes the shipping process become a problem because the sender should find the shortest route to decrees the fuel cost. The purpose of this paper is to decide the shortest route to make the shipping process from Karanganyar to Sukoharjo easier. The decission in finding the shortest route used Shortest Route Problem approach with Unsy methode. The sortest way to get to Karanganyar was 16,6 km and to Sukoharjo was 16,2 km. With using this shortest route method for the shipping to Karanganyar dan Sukoharjo is done in September 2015 and known that the different cost of the transportation was Rp 13.560,00. It means that the transportation cost can be minimized by deciding some route.
\end{abstract}

Keywords: biaya transportasi, metode Unsy, penentuan rute, shortest route problem

\section{Pendahuluan}

Kinerja sistem transportasi memegang peranan penting dalam pelayanan kepada pelanggan karena harus menjamin mobilitas produk di antara berbagai simpul sistem dengan efisiensi tinggi dan ketepatan waktu serta pada saat yang sama harus dapat mengurangi biaya transportasi, yang dalam kasus tertentu, dapat mengkonsumsi 50\% dari total biaya logistik perusahaan (Srivastava dan Benton, 1990). Biaya transportasi, tergantung pada rute kendaraan pengiriman dan kapasitas angkut kendaraan yang dikaitkan dengan total permintaan pelanggan yang dilayani pada suatu rute (Bektas, 2006).

Perusahaan printpro adalah perusahaan yang bergerak di bidang percetakan, adapun beberapa produk yang dihasilkan berupa kartu undangan, buku nikah, buku yasin, dan lainnya. Untuk produk yasin, tidak diproduksi sendiri oleh percetakan printpro melainkan diambil dari percetakan lain, dan pihak perusahaan hanya menjual dengan sistem ready stock. Untuk proses pemesanan biasanya dapat memesan produk lewat telepon, email, dan media sosial lainnya. Pesanan yang masuk akan dicatat oleh pihak perusahaan dan kemudian akan diproduksi dalam kurun waktu kurang lebih satu bulan sesuai dengan kesepakatan dengan pihak pembeli.

Proses pengiriman produk dibagi menjadi dua, yaitu untuk pengiriman jarak dekat yang meliputi daerah Solo dan sekitarnya seperti Sukoharjo, Karanganyar, Jebres, Klaten, Sragen, dll. dan pengiriman jarak jauh biasanya di luar kota Solo seperti Bandung, Semarang, dll. Untuk pengiriman daerah Solo dan sekitarnya produk dikirim dengan menggunakan motor untuk jumlah yang sedikit, dan untuk jumlah pengiriman produk dalam jumlah besar biasanya

\footnotetext{
${ }^{*}$ Correspondance : aulhmd@gmail.com
} 
menggunakan taksi. Sementara itu, untuk pengiriman di luar kota Solo, biasanya menggunakan jasa pengiriman via JNE dan TIKI untuk jumlah pengiriman sedikit, dan untuk jumlah pengiriman dalam jumlah besar biasanya menggunakan jasa kargo.

Seperti yang digambarkan pada Gambar 1, dalam proses pengiriman perusahaan percetakan printpro mengalami beberapa kendala yang mengakibatkan tingginya biaya transportasi, diantaranya yaitu kendala dari segi proses, manusia, manajemen, dan peralatan. Kendala dari segi proses disebabkan oleh waktu pengiriman yang tidak pasti, bahkan terkadang dilakukan pada saat jam-jam istirahat sehingga mengalami kemacetan saat melakukan pengiriman. Selain itu, jika terdapat retur produk yang dilakukan konsumen dikarenakan terdapat produk yang tidak sesuai spesifikasi konsumen mengakibatkan perusahaan harus melakukan pengiriman ulang produk sedangkan biaya transportasi ditanggung oleh perusahaan.

Kendala dari segi manusia, waktu pengiriman yang tidak pasti menyebabkan kurir yang melakukan pengiriman berbeda. Berbedanya kurir dalam proses pengiriman menyebabkan penggunaan rute yang berbeda sehingga dapat menyebabkan biaya transportasi yang tinggi. Setiap kurir yang melakukan proses pengiriman menggunakan rute yang berbeda untuk mencapai alamat tujuan tergantung pada rute yang diketahui oleh kurir tersebut, sehingga jika pada proses pengiriman ke alamat yang sama menggunakan kurir yang berbeda maka kemungkinan besar penggunaan rute juga berbeda. Kendala dari segi manajemen, produk yang dihasilkan oleh percetakan printpro yaitu kartu undangan, stiker, hardcover, produk ini dapat dipesan oleh umum bukan hanya untuk instansi tertentu ataupun pelanggan tetap. Hal ini menyebabkan produk dapat dipesan oleh pemesan yang berbeda, pemesan yang berbeda menyebabkan alamat pengiriman juga berbeda. Berbedanya alamat pengiriman ini menyebabkan perusahaan harus menggunakan rute terpendek untuk melakukan pengiriman tercepat, karena semakin jauh rute yang dipilih maka biaya yang diambil akan semakin besar pula. Kendala dari segi peralatan yaitu penggunaan dari taksi yang akan menyebabkan tingginya biaya yang dikeluarkan hanya untuk pengiriman.

\section{CAUSE EFFECT DIAGRAM}

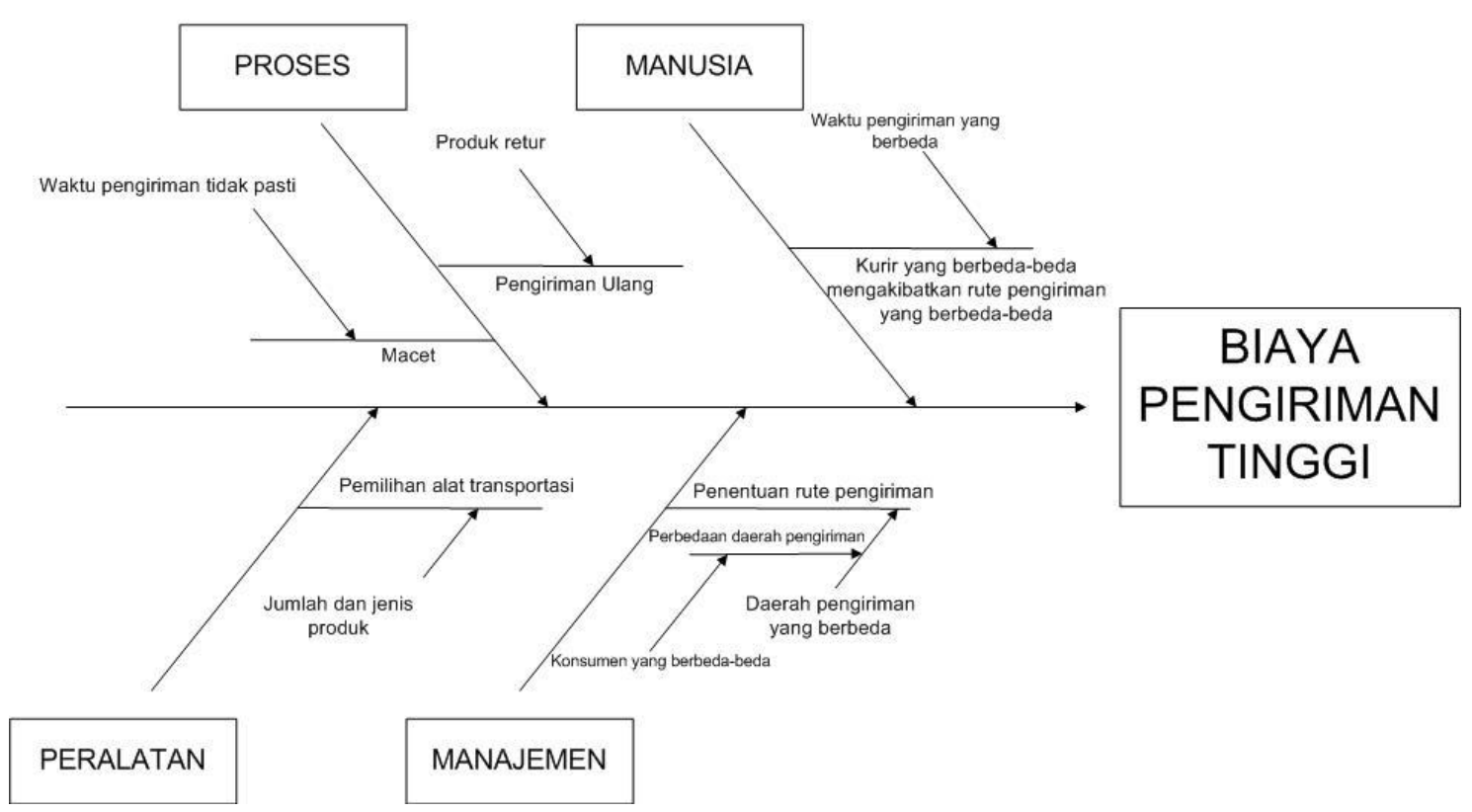

Gambar 1. Diagram Sebab - Akibat 
Selanjutnya dari masing-masing kendala dilakukan analisis biaya untuk mengetahui masalah yang memberikan kontribusi terbesar kerugian yang selanjutnya akan dilakukan pencarian solusi.

Kemudian dari masalah tersebut dilakukan analisis yang merupakan kontribusi kerugian terbesar yang selanjutnya akan dilakukan pencarian solusi. Dilihat dari segi biaya transportasi diperoleh bahwa pemilihan rute memiliki biaya kerugian yang lebih besar jika dibandingkan dengan proses (macet dan retur), sedangkan jika dilihat dari segi manusia yang disebabkan oleh berbedanya kurir yang melakukan pengiriman menyebabkan berbedanya rute yang dipilih akan mengarah pada pemilihan rute tercepat dan dari segi peralatan jika dilakukan investasi peralatan yaitu mobil untuk mengatasi biaya taksi yang tinggi tidak mungkin dilakukan karena akan menimbulkan biaya investasi yang besar sedangkan pengiriman yang dilakukan dengan menggunakan mobil tidak terlalu sering dilakukan.

Berdasarkan penjelasan diatas dapat disimpulkan bahwa kontribusi kerugian terbesar yaitu pemilihan rute, sehingga tujuan dilakukannya penelitian ini adalah untuk mengetahui rute pengiriman terbaik bagi perusahaan sehingga biaya transportasi dapat diminimalisir.

\section{Metode Penelitian}

Penelitian ini dilakukan di Perusahaan Percetakan Printpro Surakarta dengan jenis penelitian studi kasus. Subjek penelitian adalah rute pengiriman dari lokasi perusahaan yang berada di daerah Kauman, Pasar Kliwon ke lokasi pengiriman yaitu di daerah Solo dan sekitarnya. Metode penelitian dilakukan sesuai dengan gambar dibawah ini.

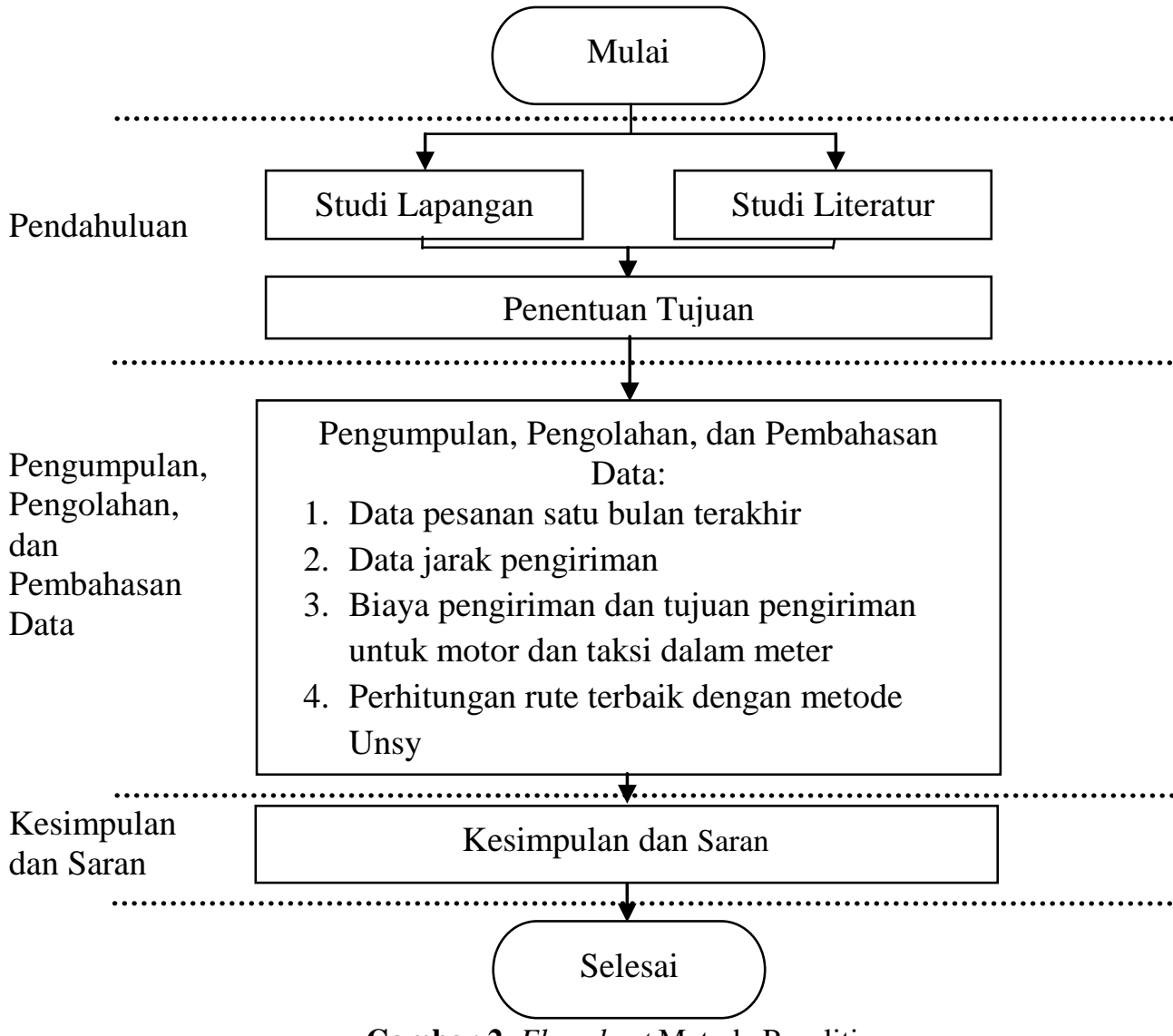

Gambar 2. Flowchart Metode Penelitian

Penelitian ini dimulai dengan studi lapangan dan studi leteratur. Studi lapangan dilakukan dengan metode wawancara kepada pemilik percetakan printpro, sedangkan 
studi literatur dilakukan dengan mencari literatur yang berhubungan dengan tema yang akan dibahas, studi literatur berasal dari jurnal dan buku. Berdasarkan wawancara yang telah dilakukan selanjutnya dilakukan pencarian kerugian kontribusi terbesar, hasil dari kerugian kontribusi terbesar selanjutnya akan digunakan sebagai masalah yang dibahas. Selanjutnya menentukan tujuan berdasarkan permasalahan yang telah diperoleh.

Data-data hasil pengumpulan data selanjutnya dilakukan pengolahan dengan pendekatan Shortest route problem yaitu metode Unsy. Pengolahan ini dibantu dengan menggunakan google maps untuk membantu memperoleh rute pengiriman terbaik. Selanjutnya dilakukan perbandingan biaya pengiriman.

Langkah terakhir yaitu melakukan penarikan kesimpulan dan saran berdasarkan penelitian yang telah dilakukan.

\section{Hasil dan Pembahasan}

Pada bab ini dijelaskan mengenai hasil dan penjelaskan tentang pemilihan rute terpendek dengan menggunakan pendekatan Shortest route problem dengan metode Unsy. Pada kasus ini metode Unsy digunakan untuk menyelesaikan permasalahan mencari rute terpendek dalam pengiriman produk di percetakan printpro untuk daerah Karanganyar dan Sukoharjo. Lokasi Karanganyar dan Sukoharjo terpilih sebagai lokasi tempat tujuan dikarenakan lokasi tersebut merupakan lokasi dengan lokasi tujuan pengiriman terbanyak. Informasi pengiriman tersebut diperoleh dari wawancara yang telah dilakukan sebelumnya. Jarak tempuh ke lokasi tujuan diperoleh dengan menggunakan bantuan aplikasi google maps dimana daerah tujuan merupakan pusat dari daerah Karangayar dan Sukoharjo. Penggunaan pusat daerah dikarenakan daerah pengiriman yang tidak pasti, bisa jadi pengiriman untuk daerah di pinggir Sukoharjo dan Karanganyar yang lebih dekat dari Kauman ataupun daerah ujung yang lebih jauh dari Kauman, sehingga penggunaan pusat dapat mewakili daerah ujung dan pinggir Sukoharjo serta Karanganyar, atau dengan kata lain jarak yang ditempuh tidak terlalu berbeda jauh.

Analisis biaya transportasi pada periode September 2015 seperti pada gambar dibawah ini.

Tabel 1. Data Biaya Transportasi Awal

\begin{tabular}{|c|c|c|c|c|c|}
\hline No & Nama & $\begin{array}{c}\text { Jenis } \\
\text { Angkutan }\end{array}$ & $\begin{array}{c}\text { Tujuan } \\
\text { Pengiriman }\end{array}$ & $\begin{array}{c}\text { Jarak } \\
(\mathbf{k m})\end{array}$ & Jumlah \\
\hline 1 & Ibu Hendi & Taksi & Boyolali & 30 & Rp 126,000 \\
\hline 2 & Mb Febri & Taksi & Jebres & 10 & Rp 46,000 \\
\hline 3 & Mb Mitha & Taksi & Karanganyar & 17 & $\mathrm{Rp} \quad 74,000$ \\
\hline 4 & Ibu Diyah & Taksi & Jebres & 9 & Rp 42,000 \\
\hline 5 & Ibu Saraswati & Taksi & Jebres & 9.5 & Rp 44,000 \\
\hline 6 & Mb Yulia & Taksi & Kartasuro & 10 & Rp 46,000 \\
\hline 7 & Ibu Sugiyanti & Taksi & Klaten & 37 & Rp 154,000 \\
\hline 8 & Gunadi & Motor & Sukoharjo & 11 & Rp $\quad 6,600$ \\
\hline 9 & Ibu Erni & Motor & Sukoharjo & 13 & Rp $\quad 7,800$ \\
\hline 10 & Mas Ari & Motor & Wonogiri & 58 & Rp 34,800 \\
\hline 11 & Bu Widi & Motor & Wonogiri & 61 & Rp 36,600 \\
\hline 12 & dr. Ari & JNE & Bandung & & Rp 100,000 \\
\hline 13 & Mb Lia & Motor & Banjarsari & 7 & Rp $\quad 4,200$ \\
\hline 14 & Bp Bambang & Motor & Sragen & 33 & Rp 19,800 \\
\hline 15 & Mas Wiwin & Motor & Mojosongo & 12 & Rp 7,200 \\
\hline 16 & Bp Dirham & Motor & Laweyan & 4 & 2,400 \\
\hline 17 & Dr. Nur & Motor & Pasar Kliwon & 2 & 1,200 \\
\hline 18 & Dr. Guntur & Motor & Sukoharjo & 15 & Rp $\quad 9,000$ \\
\hline 19 & Bp Bambang & Motor & Karanganyar & 30 & $\mathrm{Rp} \quad 18,000$ \\
\hline 20 & Ibu Bandiyoko & Motor & Karanganyar & 35 & $\mathrm{Rp} \quad 21,000$ \\
\hline 21 & MJK & Motor & Jebres & 9 & $\mathrm{Rp} \quad 5,400$ \\
\hline \multicolumn{5}{|c|}{$\overline{\text { TOTAL }}$} & Rp 806,000 \\
\hline
\end{tabular}


Berdasarkan tabel tersebut diketahui bahwa terdapat 21 pengiriman yang terjadi pada periode September 2015, terdapat pengiriman dengan menggunakan taksi dan motor, hal ini disesuaikan dengan jumlah dan jenis produk yang dikirim, jika memungkinkan menggunakan motor maka pengiriman akan dilakukan dengan menggunakan motor, jika tidak memungkinkan maka pengiriman dengan taksi. Pada pengiriman 12 pengiriman dilakukan dengan menggunakan jasa pengiriman (JNE), hal ini dikarenakan pengiriman dilakukan ke Bandung. Selain itu, pada pengiriman ke 20, pengiriman dilakukan pada siang hari, kondisi jalan sedang mengalami kemacetan sehingga jarak tempuh yang dilakukan kurir menjadi semakin jauh. Dengan menggunakan biaya taksi sebesar Rp 6000+4000/km dan biaya motor sebesar Rp 9000/15 km diperoleh total biaya transportasi sebesar Rp 806.000,00.

Selanjutnya dilakukan perhitungan jika dilakukan perbaikan terhadap masalah yang terjadi. Seperti pada gambar berikut ini.

Tabel 2. Data Perkiraan Biaya Transportasi Akhir

\begin{tabular}{|c|c|c|c|c|c|c|}
\hline No & Nama & $\begin{array}{c}\text { Jenis } \\
\text { Angkutan }\end{array}$ & $\begin{array}{c}\text { Tujuan } \\
\text { Pengiriman }\end{array}$ & Masalah & $\begin{array}{c}\text { Jarak } \\
\text { (km) }\end{array}$ & jumlah \\
\hline 1 & Ibu Hendi & Taksi & Boyolali & rute & 29.6 & $\operatorname{Rp} 109,100$ \\
\hline 2 & Mb Febri & Taksi & Jebres & rute & 4.3 & Rp 20,550 \\
\hline 3 & Mb Mitha & Taksi & Karanganyar & rute & 20.5 & Rp 77,250 \\
\hline 4 & Ibu Diyah & Taksi & Jebres & rute & 4.3 & Rp 20,550 \\
\hline 5 & Ibu Saraswati & Taksi & Jebres & rute & 4.3 & Rp 20,550 \\
\hline 6 & Mb Yulia & Taksi & Kartasuro & rute & 10.6 & Rp 42,600 \\
\hline 7 & Ibu Sugiyanti & Taksi & Klaten & rute & 37 & $\operatorname{Rp~135,000}$ \\
\hline 8 & Gunadi & Motor & Sukoharjo & rute & 12.9 & Rp $\quad 7,740$ \\
\hline 9 & Ibu Erni & Motor & Sukoharjo & rute & 12.9 & $\begin{array}{ll}\mathrm{Rp} & 7,740 \\
\end{array}$ \\
\hline 10 & Mas Ari & Motor & Wonogiri & rute & 53.1 & Rp 31,860 \\
\hline 11 & Bu Widi & Motor & Wonogiri & rute & 53.1 & Rp 31,860 \\
\hline 12 & dr. Ari & JNE & Bandung & Retur produk & & $R p$ \\
\hline 13 & Mb Lia & Motor & Banjarsari & rute & 6.1 & Rp 3,660 \\
\hline 14 & Bp Bambang & Motor & Sragen & rute & 35.2 & Rp 21,120 \\
\hline 15 & Mas Wiwin & Motor & Mojosongo & rute & 4.2 & Rp 2,520 \\
\hline 16 & Bp Dirham & Motor & Laweyan & rute & 6.7 & Rp 4,020 \\
\hline 17 & Dr. Nur & Motor & Pasar Kliwon & rute & 1.8 & 1,080 \\
\hline 18 & Dr. Guntur & Motor & Sukoharjo & rute & 12.9 & Rp $\quad 7,740$ \\
\hline 19 & Bp Bambang & Motor & Karanganyar & rute & 20.5 & Rp 12,300 \\
\hline 20 & Ibu Bandiyoko & Motor & Karanganyar & $\begin{array}{l}\text { Macet (pengiriman } \\
\text { jam makan siang) }\end{array}$ & 20.5 & Rp 12,300 \\
\hline 21 & MJK & Motor & Jebres & rute & 4.3 & $\begin{array}{ll}\mathrm{Rp} & 2,580 \\
\end{array}$ \\
\hline \multicolumn{6}{|c|}{$\overline{\text { TOTAL }}$} & Rp 572,120 \\
\hline
\end{tabular}

Pada tabel tersebut masalah yang dihadapi yaitu rute yang lebih pendek, adanya retur produk, dan terjadinya macet. Sehingga, diperoleh total biaya transportasi sebesar Rp $572.120,00$

Tabel 3. Data Total Kerugian

\begin{tabular}{|c|c|c|}
\hline \multicolumn{2}{|l|}{ TOTAL KERUGIAN } & Rp 233,880 \\
\hline \multirow{2}{*}{ Pemilihan Rute } & Awal & Rp 685,000 \\
\hline & Akhir & Rp 559,820 \\
\hline \multicolumn{2}{|c|}{ Jumlah Rugi } & $\mathrm{Rp} 125,180$ \\
\hline \multirow{2}{*}{ Macet } & Awal & Rp 21,000 \\
\hline & Akhir & Rp 12,300 \\
\hline \multicolumn{2}{|c|}{ Jumlah Rugi } & 8,700 \\
\hline \multirow{2}{*}{ Retur } & Awal & $\mathrm{Rp} 100,000$ \\
\hline & Akhir & $\mathrm{Rp}$ \\
\hline \multicolumn{2}{|c|}{ Jumlah Rugi } & Rp 100,000 \\
\hline
\end{tabular}

Berdasarkan tabel tersebut diperoleh bahwa dari segi manajemen yaitu pemilihan rute memberikan kontribusi kerugian sebesar Rp 125.180,00, sedangkan dari segi proses yaitu 
kemacetan dan produk retur (proses) memberikan kontribusi kerugian sebesar Rp 108.700,00.

Berikut ini adalah pemilihan rute terpendek:

a. Pemilihan rute terpendek dengan spanning tree untuk daerah Karanganyar

Berikut adalah spanning tree untuk pengiriman produk printpro untuk daerah Karanganyar, dengan aturan sebagai berikut :

Tabel 4. Simbol dan Nama Tempat

\begin{tabular}{|c|l|}
\hline Simbol & \multicolumn{1}{|c|}{ Nama Tempat } \\
\hline 1 & Kauman \\
\hline 2 & Il. Brigjen Katamso \\
\hline 3 & Il. Ir. Juanda \\
\hline 4 & Il. Kolonel Sutanto \\
\hline $\mathbf{5}$ & Jurug \\
\hline $\mathbf{6}$ & Palur \\
\hline $\mathbf{7}$ & Jaten \\
\hline $\mathbf{8}$ & Papahan \\
\hline $\mathbf{9}$ & Karanganyar \\
\hline
\end{tabular}

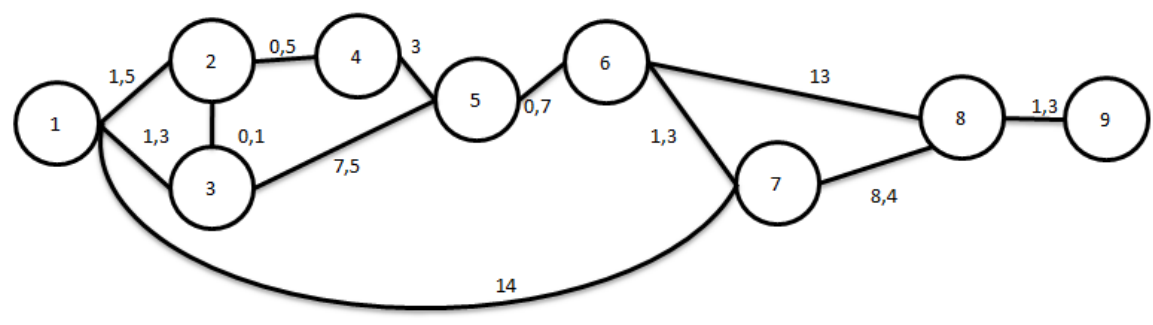

Gambar 3. Spanning tree daerah Karanganyar

Tabel 5. Proses Pencarian Rute Terpendek Daerah Karanganyar Dengan Metode Unsy

\begin{tabular}{|c|c|c|c|c|c|c|c|c|c|c|c|c|c|c|c|c|c|c|c|c|c|c|c|}
\hline \multirow{2}{*}{$\mathrm{T}$} & \multicolumn{2}{|c|}{ Level 1} & \multicolumn{3}{|c|}{ Level 2} & \multicolumn{3}{|c|}{ Level 3} & \multicolumn{3}{|c|}{ Level 4} & \multicolumn{3}{|c|}{ Level 5} & \multicolumn{3}{|c|}{ Level 6} & \multicolumn{3}{|c|}{ Level 7} & \multicolumn{3}{|c|}{ Level 8} \\
\hline & Titik & Jarak & Titik & Jarak & Total & Titik & Jarak & Total & Titik & Jarak & Total & 1 Titik & Jarak & Total & Titik & Jarak & Total & Titik & Jarak & Total & Titik & Jarak & Total \\
\hline \multirow[t]{6}{*}{9} & \begin{tabular}{|l|}
$8-9$ \\
\end{tabular} & \begin{tabular}{|l|}
1.3 \\
\end{tabular} & \begin{tabular}{|l|}
$6-8$ \\
\end{tabular} & 13 & \begin{tabular}{|l|}
14.3 \\
\end{tabular} & <-- Eli & iminas & & & & & & & & & & & & & & & & \\
\hline & & & $7-8$ & 8.4 & 9.7 & 6-7 & \begin{tabular}{|l|}
1.3 \\
\end{tabular} & 11.0 & $5-6$ & 0.7 & 11.7 & $4-5$ & 3 & \begin{tabular}{|l|}
14.7 \\
\end{tabular} & $2-4$ & 0.5 & 15.2 & $1-2$ & 1.50 & $\mid 16.7$ & $<-\mathrm{El}$ & limina & \\
\hline & & & & & & & & & & & & & & & & & & $3-2$ & 0.10 & 15.3 & $1-3$ & 1.3 & 16.6 \\
\hline & & & & & & & & & & & & $3-5$ & 7.5 & 19.2 & <-- Eli & imina & & & & & & & \\
\hline & & & & & & & & & & & & & & & & & & & & & & & \\
\hline & & & & & & $1-7$ & 14 & 23.7 & $<-\mathrm{El}$ & liminas & & & & & & & & & & & & & \\
\hline
\end{tabular}

Proses dengan metode Unsy diawali dengan memperhatikan semua titik yang berhubungan langsung dengan titik tujuan. Titik tujuan yaitu titik 9 atau daerah Karanganyar, titik yang berhubungan langsung dengan titik tujuan yaitu titik 8, titik 8-9 ini membentuk jaringan level 1 , selanjutnya titik 8 didahului oleh titik 7 dan titik 6 , masing-masing membentuk jaringan level 2, pada level ini dilakukan eliminasi yaitu pada jaringan 6-8-9 karena total jarak yang ditimbulkan menjadi lebih besar yaitu 14,3 $\mathrm{km}$, sehingga dipilih jaringan 7-8-9.

Titik 7 didahului oleh titik 6 dan titik 1, dimana titik 1 merupakan titik awal, ini membentuk jaringan level 3, pada jaringan 1-7-8-9 menghasilkan total jarak sebesar 23,7 km. sedangkan jaringan 6-7-8-9 menghasilkan total jarak $11 \mathrm{~km}$, pada level ini tidak bisa dilakukan eliminasi karena pada 1-7-8-9 sudah mencapai titik awal, jaringan ini akan dibandingkan dengan jaringan lain setelah diketahui total jarak.

Titik 6 didahului oleh titik 5 yang menghasilkan level 4, membentuk jaringan 56-7-8-9 dengan total jarak 11,7. Titik 5 didahului oleh titik 4 dan titik 3 yang membentuk level 5, pada level ini jaringan 3-5-6-7-8-9 dieliminasi karena menghasilkan total jarak 19,2 km dan jaringan 4-5-6-7-8-9 terpilih karena menghasilkan 
total jarak yang lebih kecil yaitu $14,7 \mathrm{~km}$. Titik 4 didahului oleh titik 2 yang membentuk level 6, pada level ini terpilih jaringan 2-4-5-6-7-8-9.

Titik 2 didahului oleh titik 1 dan 3 yang membentuk level 7. Pada level ini jaringan 1-2-4-5-6-7-8-9 karena memiliki jarak yang lebih besar, dan jaringan yang terpilih yaitu 3-2-4-5-6-7-8-9. Titik 3 didahului oleh titik 1 dan membentuk level 8, pada titik ini jaringan yang terpilih yaitu 1-3-2-4-5-6-7-8-9 dengan jarak 16,6 km. jika dibandingkan dengan jaringan 1-7-8-9 yang diketahui dari level 2 maka jaringan yang memiliki rute terpendek yaitu pada jaringan 1-3-2-4-5-6-7-8-9 karena memiliki total jarak lebih kecil yaitu 16,6 km dengan rincian rute yang ditempuh melalui Kauman - Jl. Ir. Juanda - Jl. Brigjen Katamso - Jl. Kolonel Katamso - Jurug - Palur - Jaten Papahan - Karanganyar.

b. Pemilihan rute terpendek dengan metode Unsy untuk daerah Sukoharjo

Berikut adalah spanning tree untuk pengiriman produk printpro untuk daerah Sukoharjo, dengan aturan sebagai berikut :

Tabel 6. Simbol dan Nama Tempat

\begin{tabular}{|c|l|}
\hline Simbol & \multicolumn{1}{|c|}{ Tempat } \\
\hline 1 & Kauman \\
\hline 2 & Keraton \\
\hline 3 & Jl.Solo Baru \\
\hline 4 & Telukan \\
\hline 5 & Jl. Solo Wonogiri \\
\hline 6 & Cuplik \\
\hline 7 & Bekonang \\
\hline 8 & Sukoharjo \\
\hline
\end{tabular}

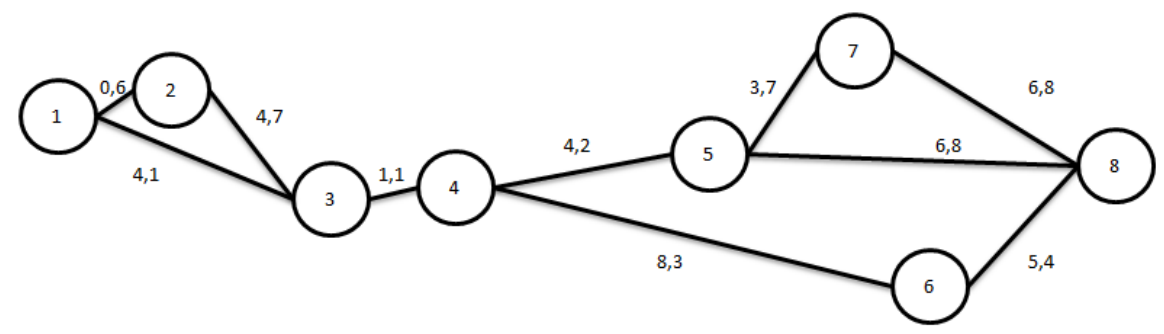

Gambar 4. Spanning tree daerah Sukoharjo

Tabel 7. Proses Pencarian Rute Terpendek Daerah Sukoharjo Dengan Metode Unsy

\begin{tabular}{|c|c|c|c|c|c|c|c|c|c|c|c|c|c|c|c|}
\hline \multirow{2}{*}{$\mathrm{T}$} & \multicolumn{2}{|c|}{ Level 1 } & \multicolumn{3}{|c|}{ Level 2 } & \multicolumn{3}{c|}{ Level 3 } & \multicolumn{3}{c|}{ Level 4 } & \multicolumn{3}{c|}{ Level 5 } \\
\cline { 2 - 15 } & Titik & Jarak & Titik & Jarak & Total & Titik & Jarak & Total & Titik & Jarak & Total & Titik & Jarak & Total \\
\hline 8 & $5-8$ & 6.8 & $4-5$ & 4.2 & 11 & $3-4$ & 1.1 & 12 & $1-3$ & 4.1 & 16.2 & & & \\
\hline & & & & & & & & & $2-3$ & 4.7 & 16.8 & <-- Eliminasi \\
\hline & $6-8$ & 5.4 & $4-6$ & 8.3 & 13.7 & <-- Eliminasi & & & & & & \\
\hline & $7-8$ & 6.8 & $5-7$ & 3.7 & 10.5 & <-- Eliminasi & & & & & & \\
\hline
\end{tabular}

Titik tujuan yaitu titik 8 atau daerah Sukoharjo, titik yang berhubungan langsung dengan titik tujuan yaitu titik 5,6 , dan 7 , titik 5-8, 6-8, dan 7-8 ini membentuk jaringan level 1, dimana 5-8 berjarak 6,8 km, 6-8 berjarak 5,4 km, dan 7-8 berjarak 6,8 $\mathrm{km}$. Selanjutnya titik 5 dan 6 didahului oleh titik 4 dan titik 7 didahului oleh titik 5, masing-masing membentuk jaringan level 2, pada level ini dilakukan eliminasi yaitu pada jaringan 4-6-8 dan 5-7-8 karena total jarak yang ditimbulkan menjadi lebih besar, 
sedangakan jaringan 4-5-8 terpilih karena merupakan jaringan dengan jarak terpendek yaitu $11 \mathrm{~km}$.

Titik 4 didahului oleh titik 3, kemudian ini membentuk jaringan level 3, dimana pada jaringan 3-4-5-8 menghasilkan total jarak sebesar $12 \mathrm{~km}$. Titik 3 didahului oleh titik 2 dan 1, dimana titik 1 adalah titik awal, yang menghasilkan level 4, membentuk jaringan 1-3-4-5-8 dengan total jarak $16.2 \mathrm{~km}$ dan jaringan 2-3-4-5-8 dieliminasi karena memiliki jarak yang lebih besar.

Maka jaringan 1-3-4-5-8 terpilih karena memiliki rute yang lebih pendek dari jaringan lainnya yaitu sebesar $16.2 \mathrm{~km}$ dengan rincian rute yaitu Kauman - Jl. Solo Baru - Telukan - Jl. Solo Wonogiri - Sukoharjo.

Setelah diketahui rute pengiriman selanjutnya dilakukan perbandingan biaya sebelum dan setelah diakukan penentuan rute terbaik. Perbandingan biaya digambarkan dalam tabel dibawah ini:

Tabel 8. Perbandingan Biaya Transportasi Awal dan Akhir Daerah Karanganyar dan Sukoharjo

\begin{tabular}{|c|c|c|c|c|c|c|}
\hline \multicolumn{3}{|c|}{ Biaya Pengiriman Awal } & \multicolumn{4}{|c|}{ Biaya Pengiriman dengan Perhitungan Unsy } \\
\hline Daerah Pengiriman & Jarak & Biaya & Daerah Pengiriman & Jarak & Biay & \\
\hline \multirow{3}{*}{ Karanganyar } & 17 & Rp10,200 & \multirow{3}{*}{ Karanganyar } & 16.6 & Rp & 9,960 \\
\hline & 35 & Rp21,000 & & 16.6 & Rp & 9,960 \\
\hline & 30 & Rp18,000 & & 16.6 & Rp & 9,960 \\
\hline \multicolumn{2}{|c|}{ Jumlah } & Rp49,200 & \multicolumn{2}{|l|}{ Jumlah } & Rp & 29,880 \\
\hline \multicolumn{5}{|c|}{ Selisih Biaya Pengiriman } & \multicolumn{2}{|r|}{ Rp19,320 } \\
\hline \multirow{3}{*}{ Sukoharjo } & 11 & Rp6,600 & \multirow{3}{*}{ Sukoharjo } & 16.2 & Rp & 9,720 \\
\hline & 13 & Rp7,800 & & 16.2 & Rp & 9,720 \\
\hline & 15 & Rp9,000 & & 16.2 & Rp & 9,720 \\
\hline \multicolumn{2}{|c|}{ Jumlah } & Rp23,400 & \multicolumn{2}{|l|}{ Jumlah } & Rp & 29,160 \\
\hline \multicolumn{5}{|c|}{ Selisih Biaya pengiriman } & \multicolumn{2}{|r|}{$-\mathrm{Rp} 5,760$} \\
\hline \multicolumn{5}{|c|}{ Total Selisih Biaya Pengiriman } & \multicolumn{2}{|r|}{ Rp13,560 } \\
\hline
\end{tabular}

Berdasarkan data bulan September 2015 untuk pengiriman ke daerah Karanganyar dan Sukoharjo diperoleh perhitungan dengan metode unsy dengan biaya per $\mathrm{km}$ sebesar Rp 9000 untuk setiap $15 \mathrm{~km}$ terjadi penurunan biaya sebesar Rp 13.560,00. Dimana untuk daerah Karanganyar terjadi penurunan sebesar Rp.19.320,00 dan untuk daerah Sukoharjo terdapat selisih lebih mahal yaitu sebesar Rp.5.760,00. Penentuan jarak dalam penelitian ini menggunakan aplikasi google maps. Seperti yang telah dijelaskan sebelumnya, besar jarak yang diperoleh bisa menjadi lebih kecil seperti yang diperoleh pada pengiriman ke Karanganyar, atau bisa menjadi lebih besar seperti pada pengiriman ke Sukoharjo, hal ini tidak terlalu berpengaruh karena pengiriman ditujukan ke daerah pusat Sukoharjo dan Karanganyar, sehingga jarak yang diperoleh tidak terlalu jauh. Untuk mengatasi hal tersebut rute sebelum daerah menjadi acuan dari pengiriman, seperti pada pengiriman daerah Sukoharjo, rute sebelum Sukoharjo yaitu Jl. Solo Wonogiri, jika dari Jl. Solo Wonogiri memiliki rute yang lebih cepat ke daerah tujuan dibandingkan dengan melewati pusat Sukoharjo maka itu menjadi lebih baik dan biaya transportasi juga akan berkurang.

Karena perbandingan untuk kedua kota tersebut diperoleh hasil penurunan biaya sebesar Rp.13.560,00, maka untuk pengiriman daerah Sukoharjo dan Karanganyar menunjukkan bahwa dengan menggunakan metode penentuan rute terpendek berhasil dalam meminimalkan biaya transportasi. 


\section{Simpulan}

Berdasarkan hasil yang diperoleh, dapat diambil kesimpulan bahwa rute terpendek untuk pengiriman daerah karanganyar yaitu Kauman - Jl. Ir. Juanda - Jl. Brigjen Katamso - Jl. Kolonel Katamso - Jurug - Palur - Jaten - Papahan - Karanganyar dengan jarak 16,6 km, sedangkan rute terpendek untuk pengiriman daerah Sukoharjo yaitu Kauman - Jl. Solo Baru Telukan - Jl. Solo Wonogiri - Sukoharjo. dengan jarak 16,2 km. Dengan metode yang telah dilakukan dapat meminimumkan biaya sebesar Rp 13.560,00. Saran yang dapat diberikan penulis yaitu pemilihan rute pengiriman sebaiknya ditetapkan dari hasil dari rute terbaik dan tidak mengubah rute setiap kali pengiriman serta sebaiknya pengiriman produk dilakukan tidak saat jam-jam yang rawan kemacetan.Saran untuk penelitian selanjutnya dapat dilakukan dengan melakukan analisis kelayakan investasi jika dilakukan penambahan transportasi mobil untuk melakukan pengiriman produk yang besar sehingga tidak perlu menggunakan taksi.

\section{Daftar Pustaka}

Bektas, T. (2006). The multiple travelling salesman problem: an overview of formulations and solution procedures. The International Journal of Management Science vol. 34, no. 3, 209-219.

Srivastava, R. and Benton, W.C. (1990). The location routing problem: Considerations in physical distribution system. Computers and Operations Research, vol. 17, no. 5, pp. 427-435. 